\title{
IMPAK GENRE ORIENTALISME DALAM TAMADUN ISLAM: ANALISIS TERHADAP PERKEMBANGAN SEMASA
}

\author{
Rahimin Affandi Abd. Rahim \\ Muhammad Kamil Ab. Majid \\ Ruzman Md Nor \\ Nor Hayati Md Dahlal
}

\begin{abstract}
The genre of orientalism was a product of western-secular world-view in understanding the oriental world. At first, it seemed to be a renowned discipline without any challenge from eastern scholars. However, recently this changed due to the emergence of post-colonialism philosophy and orientalism is being seriously examining by eastern scholars. This article focusses on the subject of Muslim civilization in the Malay Archipelago in the context of orientalism. It is divided into several sections. First, we consider Malay-Muslim's perspectives toward orientalism. Second, we analyse classical orientalism's paradigm vis-a-vis the development of Muslim civilization in the Malay Achipelago. Third, an analysis of the recent trend of orientalism's paradigm of the Muslim civilization will be considered and finally a few conclusions will be made.
\end{abstract}

\section{Pengenalan}

Dalam dunia akademik, khususnya yang membabitkan kajian ketamadunan Islam di Alam Melayu, pengaruh yang diberikan oleh genre orientalisme agak besar, sama ada secara positif ataupun negatif. Dalam berhadapan dengan realiti ini, para sejarawan telah memberikan respon yang berbeza terhadap isu pengaruh ini. Hal ini secara langsung bakal memperkayakan lagi bahan kajian berkaitan dengan genre occidentalism sebagai usaha counter attack terhadap kupasan sarjana orientalis. Berasaskan latar belakang masalah ini, artikel ini bakal menganalisis sebahagian besar daripada perkembangan dan kupasan sarjana orientalis yang menyentuh isu ketamadunan Islam di Alam Melayu. Selain itu, artikel ini penting kerana bakal mengemukakan jawapan sarjana Islam semasa terhadap semua persoalan yang berkaitan dengan isu yang dikaji. 
Pendekatan Penganalisaan Terhadap Genre Orientalisme Di Dalam Pembinaan Tamadun Islam

Dalam tradisi pengajian Islam, terdapat suatu stigma yang menyatakan bahawa genre orientalisme secara mutlaknya dianggap sebagai negatif. Lebih kronik lagi, terdapat juga pandangan yang menisbahkan dunia Barat secara mutlak sebagai pusat kekuasaan gelap yang antiIslam $^{1}$ ataupun sebagai diabolisme (pengikut tabiat syaitan). ${ }^{2}$ Lanjutan daripada pandangan ini, terdapat sesetengah kumpulan yang secara berani menyatakan bahawa sesiapa sahaja yang pernah belajar dan dilihat menyebarkan paradigma pengajian yang bersifat terbuka ataupun positif dengan pusat kajian orientalisme akan dituduh sebagai tali barut orientalis yang harus ditentang habis-habisan, sehinggalah kepada peringkat sanggup mengkafirkan kalangan ini. ${ }^{3}$

Perkara yang menghairankan, semasa wujudnya pandangan yang mengutuk pusat dan genre kajian orientalisme ini, terdapat beberapa fakta yang perlu difikirkan bersama. Antaranya ialah pusat kajian orientalisme yang rata-ratanya berada di negara Barat telah dijadikan tumpuan oleh pelajar Islam dari seluruh dunia untuk meneruskan pengajian mereka di peringkat pasca siswazah. Daripada laporan yang diberikan oleh pelajar Islam sendiri yang pernah belajar di pusat terbabit, ternyata pusat kajian tersebut sememangnya mempunyai beberapa elemen positif. Antaranya ialah sistem pengajian yang agak berkesan, koleksi bahan perpustakaan (kajian primer dan sekundar) yang cukup lengkap, iklim intelektual yang kondusif, penekanan yang lebih kepada soal metodologi kajian yang terkini dan terpenting. Tujuannya adalah untuk melahirkan para sarjana Islam yang berwibawa. ${ }^{4}$

Selain itu, pusat kajian orientalisme ini telah menjadi tumpuan pelarian politik oleh sejumlah besar sarjana Islam daripada negara umat Islam seperti Timur Tengah, Indo-Pakistan dan Iran. Semasa mereka diburu dan dimusuhi oleh pemerintah umat Islam sendiri, kehadiran mereka telah diterima secara terbuka oleh pusat kajian orientalis ini. Sejarah telah mencatatkan bahawa ramai daripada tokoh gerakan Islam yang ditindas oleh pemerintah negara umat Islam telah berhijrah ke negara Barat. Mereka kemudiannya bertanggungjawab memperkembangkan semangat kebangkitan semula Islam di daerah baru yang amat kondusif (Civil society) yang mampu memberi ruang untuk memperkembangkan kebebasan intelektual. ${ }^{5} \mathrm{Hal}$ ini secara langsung telah mempengaruhi sejumlah besar pelajar-pelajar Islam yang datang daripada pelbagai negara Islam. Mengikut analisis yang dibuat oleh seorang sarjana Barat yang mengikuti perkembangan pendidikan Islam di Malaysia, tokohtokoh yang mendapat pendidikan dan latihan di peringkat ijazah tinggi 
daripada kedua-dua pusat pengajian di Timur Tengah dan Barat, pada kebiasaannya akan berkhidmat di fakulti pengajian Islam di universiti tempatan apabila kembali ke Malaysia. ${ }^{6}$

Pusat kajian orientalis memang cukup prolifik dalam melahirkan kajian kritikal terhadap subjek Islam. Apa yang uniknya, kebanyakan kajian ini bersifat telus dan membongkarkan semua kelemahan (seperti pendekatan double standard) yang diamalkan oleh pemerintah Barat terhadap dunia Islam. ${ }^{7}$ Terdapat juga pandangan yang menyatakan keunggulan formula Islam dan merendah-rendahkan formula pembangunan Barat. Sejajar dengan itu, apa yang menjadi persoalannya adalah mengapakah negara dan kepimpinan umat Islam masih berada dalam keadaan yang amat mundur terutama dari segi kualiti dan integriti, berbanding dengan masyarakat Barat. Berbeza dengan barat lebih menonjol dalam soal membangunkan pelbagai teori kepimpinan moden, termasuklah yang mengabungkan antara pendekatan kebendaan dan spiritual.

Dalam hal ini, beberapa perkara perlu diberikan perhatian ataupun input berguna untuk proses berfikir bagi umat Islam, iaitu teori dan formula bahawa pembangunan Barat adalah cukup dinamik dan sentiasa berubah, ${ }^{8}$ realiti masyarakat dan kepimpinan politik Barat yang lebih telus dan demokratik (civil society). Barat amat menitikberatkan soal penjagaan sistem ekologi dunia, realiti kepimpinan politik Barat yang lebih suka berpegang kepada hasil penyelidikan yang dijalankan oleh para ilmuan di samping tahap kemajuan ekonomi mereka yang lebih maju, khususnya membabitkan penguasaan dunia Barat terhadap seluruh sistem di dunia. Hal ini adalah disebabkan oleh kecanggihan ilmu pengetahuan yang mampu mendominasi semua elemen kehidupan dunia moden.

Berasaskan kepada kesemua fakta ini, penulisan ini akan menggunakan pendekatan yang lebih adil, terbuka dan selektif di dalam menilai genre orientalisme khususnya yang berkaitan dengan sejarah tamadun Islam di Alam Melayu. Ini bermakna, kaedah penilaian yang bakal dipilih agak berbeza dengan pendekatan anti melulu yang biasanya dipakai oleh sarjana Islam semasa. Mengikut hemat para penulis, paradigma ini memang mempunyai justifikasinya dalam sejarah tamadun keilmuan Islam sendiri. Hal ini ditegaskan dengan cukup tuntas oleh Wan Mohd Nor Wan Daud apabila meneliti sikap negatif terhadap genre orientalisme. Beliau telah menegaskan bahawa terdapat sejumlah besar sarjana Islam yang telah dijangkiti penyakit westophobia, sikap takut dan benci yang tidak rasional terhadap Barat. Pada dasarnya, penyakit ini adalah serpihan daripada penyakit akal, xenophobia yang menyebabkan pengidapnya sentiasa takut kepada unsur-unsur luar. ${ }^{9}$ 
Dalam proses pembinaan tamadun Islam di Malaysia sepertimana terkandung dalam konsep Islam Hadhari, beberapa pendekatan tertentu perlu digunakan. Antara pendekatan tersebut ialah mempelajari elemen positif daripada tamadun luar. Misalnya bagaimana sesuatu tamadun Barat membangunkan tamadun mereka dengan berkesan dan mengamalkan pendekatan autokritik ataupun penganalisaan tentang kelemahan dalaman umat Islam. Hal ini boleh dilakukan dengan mempelajari apa yang dilakukan oleh tamadun Barat.

Secara kasarnya, terdapat beberapa faedah genre orientalisme yang boleh dimanafaatkan bagi program pembinaan tamadun Islam secara amnya dan tamadun Islam di Malaysia khususnya. Melihat kepada genre orientalisme memang banyak menekankan elemen terpenting bagi pembinaan tamadun kemanusiaan yang agung seperti penekanan terhadap faktor agama dan budaya ilmu yang biasanya menjadi punca dan teras utama kepada pembentukan sesuatu tamadun. Hal ini juga dapat dilihat intipati secara langsung daripada kesungguhan sarjana orientalis yang mengkaji karya-karya yang dihasilkan oleh ilmuan Islam dalam pelbagai bidang seperti Ibn Khaldun, al-Mawardi, Tabari dan sebagainya.

Sehubungan dengan itu, kupasan daripada sarjana orientalis telah mengalakkan sarjana Islam menjalankan pendekatan responsif dengan menjawab segala tohmahan buruk yang diutarakan oleh sarjana orientalis. Dari segi pencambahan pemikiran Islam, sikap leka dan nastolgia dengan pencapaian tamadun silam biasanya akan menyebabkan daya ketajaman analisis-kritikal tidak akan berlaku, sebaliknya seandainya intellectual discourse itu sentiasa berlaku sama ada dalam bentuk penerimaan ataupun penolakan terhadap sesuatu idea, ianya bakal menjana wujudnya perkembangan pemikiran yang sihat. Dalam soal ini, beberapa contoh yang agak relevan boleh diutarakan seperti:

Pertama; pandangan Hazarain dengan Teori Receptio in complexu yang menjawab dan menolak teori Reception Exit yang dikemukakan oleh Snouck Hurnonje. Teori Receptio in complexu menegaskan bahawa dengan wujudnya institusi politik dan pendidikan Islam yang cukup kuat dalam masyarakat Melayu-Islam, hukum Islam telah mendapat tempat yang cukup kuat dalam masyarakat sehingga ianya telah menjadi adat kebiasaan (' $u r f$ ) dan asas untuk jati diri dalam masyarakat Melayu. Ianya telah sebati menjadi elemen pola cita dan kelakuan di dalam kebudayaan Melayu. Manakala Teori Reception Exit ditimbulkan bagi mengajar penjajah Belanda dan masyarakat Islam di Indonesia tentang bagaimana mengatur kehidupan beragama (pengamalan hukum Islam). Kedatangan 
kuasa penjajah Barat yang menguasai ruang politik dan epistemologi masyarakat Melayu dirancang bagi mengugat perkembangan sestem perundangan Islam yang selama ini telah secara tuntas dijalankan. Pihak penjajah Barat berpandukan teori Reception Exit ini telah meminggirkan hukum Islam yang dikatakan bersifat ketinggalan dan perlu diganti dengan sistem perundangan Barat yang kononnya lebih bersifat moden. Usaha penjajah ini kemudiannya semakin parah lagi apabila sistem pendidikan perundangan ala Barat diperkenalkan menggantikan sistem pendidikan Islam yang dipinggirkan daripada arus perdana. Akibatnya, telah lahir beberapa orang pengamal undang-undang di Malaysia yang begitu taksub dengan sistem perundangan Barat. ${ }^{10}$

Kedua; pandangan Hooker yang memandang rendah sumbangan ulama Melayu silam yang dikatakan sebagai hanya penterjemah karya-karya ulamak Timur Tengah yang baik tanpa disertakan dengan daya analisis yang memasukkan pandangan ulama Melayu sendiri. Beliau juga mendakwa bahawa tiada suatu pun karya ilmu usul al-fiqh yang mengupas elemen pemikiran hukum Islam yang tersebar di Alam Melayu. Hal ini telah ditolak oleh sejumlah sarjana Melayu seperti Ismail Mat yang menegaskan bahawa ulama Melayu silam secara tuntas telah mengulas dan melakukan elemen sintesis yang memperkayakan karya Timur Tengah dengan nilai tempatan ('uruf) Melayu. Contohnya, Hukum Kanun Melaka mustahil dapat dihasilkan oleh sarjana Melayu tanpa berasaskan kepada pemahaman ilmu usul al-fiqh yang jitu. ${ }^{11}$

Ketiga; teori yang dikemukakan oleh sarjana orientalis yang memperkecilkan peranan Islam dalam masyarakat Melayu. Mereka mendakwa bahawa Islam hanyalah selaput luar daripada diri masyarakat Melayu, sedangkan isi dalamannya masih lagi secara kuat berpegang kepada ajaran Hindu-Budha. Teori ini secara langsung telah ditolak oleh Syed Muhammad Naquib al-Attas yang membuktikan bagaimana proses Islamisasi Alam Melayu telah berjaya menghakis saki baki ajaran pra Islam dalam diri masyarakat Melayu yang digantikan dengan unsur rasionalisme yang cukup tinggi. ${ }^{12}$

Keempat; kajian yang dilakukan oleh Abdul Aziz Mat Ton yang telah menolak tohmahan dan pendapat William Roff yang memandang rendah sumbangan yang diberikan oleh majalah al-Imam yang diusahakan oleh Kaum Muda ke arah mewujudkan semangat nasionalisme yang terawal di Tanah Melayu. Kajian Abdul Aziz Mat Ton ini telah mengubah persepsi sejarah perjuangan Islam yang dominan di Tanah Melayu. Beliau menegaskan bahawa golongan anak didik penjajah yang terdiri daripada 
pembesar Melayu merupakan tokoh ulung yang memainkan peranan membangkitkan semangat nasionalisme di Tanah Melayu. Sebaliknya, beliau telah berjaya menunjukkan bagaimana perjuangan awal Kaum Muda ini yang kemudiannya diikuti dengan kebangkitan golongan ulama Melayu telah menimbulkan pelbagai masalah kepada pihak British sehingga British terpaksa menguatkuasakan pelbagai bentuk penindasan ke atas ulama Islam. ${ }^{13}$

Kelima; kajian yang dilakukan oleh Muhammad Redzuan Othman telah menolak dakwaan William Roff yang menyatakan bahawa perkembangan kemajuan moden di Tanah Melayu merangkumi sistem pendidikan, celik huruf dan pengenalan sistem penerbitan buku dan majalah telah diperkenalkan buat pertama kalinya di Tanah Melayu oleh pihak British. Sebaliknya, hasil kajian beliau mendapati perkembangan pemodenan sebenar telah berkembang dengan begitu meluas akibat daripada hubungan intelektual yang wujud di antara rantau Alam Melayu dengan Mekah, yang merupakan pusat pertemuan dan pendidikan umat Islam sedunia. ${ }^{14}$

Selain itu, genre orientalisme secara langsung telah mendedahkan kepada dunia luar tentang tamadun Islam. Usaha ini telah dianggap sebagai pencetus awal yang bakal melahirkan pelbagai kajian susulan ataupun kajian lanjutan yang dilakukan oleh sarjana lain. Kajian ini menyentuh mengenai tamadun Islam, tidak kira ianya dalam bentuk yang positif ${ }^{15}$ ataupun negatif. ${ }^{16}$ Manakala pusat Kajian Orientalisme Barat memang cukup berpengalaman dalam menghasilkan bahan kajian yang kaya dengan unsur-unsur mechanical analisis data yang dibuat terhadap karya-karya tradisi Islam. Sebagai lanjutan dari pengunaan pendekatan historicisme dan fenomenologi, sarjana orientalis telah berusaha melakukan analisis data terhadap karya-karya klasik umat Islam. Antara bahan-bahan yang dimaksudkan ini adalah seperti Index Islamicus, Encyclopedia of Islam, Mu'jam al-Quran dan Sunnah, terjemahan tafsir Quran, Sirah Nabawi dan terjemahan terhadap karya-karya sintesis fuqaha silam. ${ }^{17}$ Hasilnya, kajian-kajian bentuk ini telah membantu proses penyelidikan yang dilakukan oleh seseorang penyelidik termasuklah penyelidik Islam sendiri.

\section{Analisis Terhadap Tren Genre Orientalism Klasik Dalam Memperihalkan Tamadun Islam}

Secara mendalamnya, beberapa paradigma pengkajian Islam yang telah diaplikasikan oleh sarjana orientalis di dalam kupasan terhadap tamadun Islam di Alam Melayu telah dapat dikesan. Antara paradigma yang 
dimaksudkan ialah:

Pertama, paradigma yang mendokong kepentingan kolonialisme Barat di Alam Melayu. Mereka telah mengkaji kebudayaan masyarakat Timur (oriental) dalam semua aspek, khususnya sifat positif dan negatif yang terdapat dalam masyarakat tersebut. Kajian ini secara langsung bertujuan untuk menjadi suaka dan alat kepada kuasa politik penjajah, ${ }^{18}$ yang menghuraikan secara lengkap tentang kekuatan dan kelemahan masyarakat Timur. Tujuannya adalah untuk dipelajari oleh kuasa penjajah demi menguatkan penguasaan mereka terhadap masyarakat tanah jajahan. ${ }^{19}$ Sifat utama kajian ini kebanyakannya cuba mendedah dan menyebarkan propaganda kononnya masyarakat Melayu adalah bersifat negatif seperti pemalas, ${ }^{20}$ suka berpoya-poya, ${ }^{21}$ bersikap keras kepala, ${ }^{22}$ tidak boleh diharap, ${ }^{23}$ suka berhutang ${ }^{24}$ dan sebagainya. Untuk memperbaiki keadaan ini, kuasa British telah dianggap sebagai penyelamat (saviour) masyarakat Melayu ${ }^{25}$ dengan memperkenalkan sistem pendidikan ala Barat yang berorientasikan materialisme dan pemupukan budaya British yang dianggap baik. Namun pendidikan yang diperkenalkan hanya dikhususkan kepada kelas feudal Melayu. ${ }^{26}$ Melalui kajian pakar-pakar pentadbir British yang mendalami budaya Melayu, ${ }^{27}$ mereka telah dapat memperkukuhkan lagi kedudukan kelas feudal Melayu. Golongan feudal Melayu ini dilatih untuk menjadi golongan yang berwajah Melayu, tetapi roh dalamannya bersifat British yang dianggap dapat dijadikan sebagai jalan perantaraan yang terbaik untuk menguasai masyarakat Melayu yang secara tradisinya begitu menghormati golongan feudal ini. ${ }^{28}$

Kedua, falsafah evolutionism yang menganggap tamadun Barat sebagai lebih tinggi dan agung, berbanding dengan keadaan masyarakat Timur. ${ }^{29}$ Pencapaian tamadun barat yang membanggakan ini kononnya disebabkan kerana penerimaan fahaman sekular yang menolak kepentingan agama dalam kehidupan manusia. ${ }^{30}$ Sebaliknya, masyarakat di sebelah Timur yang masih berpegang kepada agama dan faham metafizik telah dianggap sebagai mundur, tidak bertamadun dan harus ditamadunkan oleh masyarakat Eropah. ${ }^{31}$ Bagi mereka tugas menjajah untuk mengajar masyarakat Timur ini telah dianggap sebagai tanggungjawab sosial yang terpaksa dilaksanakan oleh masyarakat Eropah. ${ }^{32}$ Berpandukan falsafah inilah yang mendorong kebanyakan sarjana Barat yang mengkaji pengaruh syariah terhadap undang-undang adat Melayu memburuk-burukkan undang-undang Islam yang dianggap sebagai ketinggalan zaman, zalim, tidak berperikemanusiaan ${ }^{33}$ dan banyak lagi bentuk keburukan yang dinisbahkan kepada syariah Islam. ${ }^{34}$ 
Begitu juga semua sifat negatif yang dipunyai oleh orang Melayu dikatakan berpunca daripada pengamalan mereka terhadap ajaran Islam, seperti suka berserah kepada takdir, tidak menghargai masa, ${ }^{35}$ menolak pemodenan $^{36}$ dan sebagainya yang perlu diubah dengan memperkenalkan cara hidup Barat, termasuklah sistem undang-undang ala keeropahan. ${ }^{37}$

Ketiga, pendekatan diffusionism yang menganggap kemajuan masyarakat Melayu bukan kerana sifat asal diri mereka yang baik dan proaktif terhadap sesuatu kemajuan, ${ }^{38}$ tetapi disebabkan oleh pengaruh budaya asing (difusi budaya) yang secara langsung telah ditiru secara selektif oleh masyarakat Melayu. ${ }^{39}$ Sikap ini secara terang-terangan telah menafikan kepandaian masyarakat tempatan (local genius) dalam membina sesuatu tamadun tempatan yang tinggi ${ }^{40}$ Antara budaya asing yang kononnya telah mencirikan kebudayaan Melayu adalah HinduBudha, Arab, India dan Parsi. Bahkan apabila mengkaji pengaruh Islam terhadap jati diri orang Melayu, mereka telah mengambarkannya secara skeptik dengan mengatakan bahawa masyarakat Melayu sebenarnya tidak mempunyai pegangan keIslaman yang cukup kuat, hanya di lapisan kulit luar semata-mata, sedangkan isi dalamnya masih lagi berteraskan budaya pra Islam (animisme dan Hindu). ${ }^{41}$ Secara keseluruhannya dapat dikesan bagaimana kajian mereka terhadap kebudayaan Melayu kebanyakannya berteraskan sifat anti Islam yang terbawa-bawa dari semangat perang Salib ${ }^{42}$ dan kebencian mereka terhadap pengalaman penentangan yang telah dicetuskan oleh masyarakat Islam di tanah jajahan yang berada di bawah penguasaan kuasa Barat. ${ }^{43}$

Pada permulaan abad ke-20, apabila kebanyakan dunia Islam memperoleh kemerdekaan daripada kuasa penjajah, populariti pusat kajian orientalis Barat telah mula menurun, ${ }^{44}$ tetapi kemudiannya populariti ini telah dapat bertahan lama dengan sokongan material yang diberikan oleh kuasa besar, yang memang memaklumi sumbangan besar yang pernah diberikan oleh pusat kajian orientalis ini dalam usaha memahami kekuatan dan kelemahan umat Islam. ${ }^{45}$ Atas dasar ini kuasa besar telah berusaha meneruskan kewujudan pusat orientalis ini dengan harapan ianya dapat digunakan untuk mengetahui perkembangan umat Islam dan merancang kaedah terbaik untuk mengawal kegiatan mereka. ${ }^{46}$ Pusat kajian orientalis Barat telah menukar nama pusat mereka daripada "Oriental Institute" kepada nama yang lebih umum iaitu pusat "Islamic Studies". ${ }^{47}$ Taktik ini telah berjaya menarik minat sesetengah kerajaan Islam untuk melabur dana kewangan mereka ke dalam pusat Islamic Studies ini. Hasilnya, dapat dilihat banyak pusat kajian Islamic Studies telah bergabung dengan kerajaan Islam hingga menyebabkan mereka 
memperolehi bantuan material daripada kerajaan Islam sendiri. ${ }^{48}$ Malangnya pertukaran nama dan pengabungan sumber kewangan ini tidak mengubah kaedah dan pendekatan pusat Islamic Studies ini malah masih meneruskan pendekatan ala kebaratan selain bertindak memaksa umat Islam untuk menerima pakai pendekatan mereka. ${ }^{49}$

Rentetan daripada perkembangan ini, dapat dilihat bagaimana pemerintah Islam sendiri telah terpengaruh dengan pandangan kuasa besar. Mereka juga turut menerima pakai nasihat serta pandangan tokoh orientalis moden untuk mengamalkan pendekatan anti dan menindas gerakan Islam. ${ }^{50}$ Hal ini telah dijelaskan sendiri oleh seorang pengkaji Barat yang menjelaskan:

To justify their crackdown against Islamists, the U.S. supported regimes, along with Israel, argued that Islamists could be trusted because once in power, they would dispense with constitutional check and balances and established totalitarian theocracies. The pro Western government also warned the United States against the transhistorical nature of the Islamic threat to regional stability, as well as to Western interest and values. ${ }^{51}$

\section{Analisis Kecenderungan Semasa Dalam Genre Orientalisme}

Pusat kajian orientalisme di barat bukanlah bersifat monolitik dan statik, tetapi ia sentiasa berkembang bersesuaian dengan peredaran zaman. Zaman moden yang bermula sejak dari era selepas Perang Dunia Kedua hingga sekarang banyak terpengaruh secara langsung dengan pelbagai idealisme moden yang berkembang dalam dunia akademia. Dalam soal ini, dapat dikenalpasti beberapa paradigma yang diamalkan oleh Pusat Kajian Orientalisme ini, antaranya ialah;

Pertama, penerimaan pusat kajian orientalisme Barat dengan pengaruh fahaman pasca kolonialisme moden. ${ }^{52}$ Fahaman pasca kolonialisme merupakan satu bentuk kesedaran baru yang muncul pada zaman moden. Kesedaran ini muncul adalah disebabkan oleh kegagalan sistem pemikiran Barat yang berteraskan fahaman sekular dari segenap segi dalam menghasilkan bentuk kehidupan yang bahagia kepada manusia. ${ }^{53}$ Selain itu, pendokong fahaman ini merasakan peri pentingnya semua agama besar di dunia agar bersatu dalam menanggani hegemoni fahaman sekular bentuk baru yang dibawa oleh fenomena globalisasi. ${ }^{54} \mathrm{Di}$ samping itu, wujud juga dalam kalangan mereka kesedaran ilmiah yang bersifat global yang mempersoalkan kesemua konsep ilmu dan kerangka pemodenan Barat silam, khususnya pendekatan yang terlalu menekankan subjek sains moden dan menafikan peranan subjek kemasyarakatan. ${ }^{55}$ 
Gerakan ini lebih menumpukan perhatian untuk menyepadukan kesemua bidang ilmu yang diperlukan oleh umat manusia moden, ${ }^{56}$ kesedaran tentang salahnya pandangan yang menisbahkan paradigma keilmuan Barat, khususnya Sains dan Teknologi sebagai bermanafaat, penuh dengan nilai kemanusiaan dan value free (bebas daripada nilai dan kepentingan). Ianya ternyata tidak bersifat value free kerana dibina dan dibangunkan penuh dengan pelbagai kepentingan tertentu seperti kepentingan ekonomi negara kuat ${ }^{57}$ dan kepentingan ketenteraan kuasa nuklear Barat. ${ }^{58}$ Kesedaran tentang kelemahan paradigma MaterialistikMekanisme - menganggap alam sebagai sumber utama yang berupa material- mekanis semata-mata dan tidak mempunyai nilai spiritual (nyawa) yang perlu bergantung kepada kuasa ketuhanan. Pandangan ini telah melahirkan sifat sekularis dan individualistic yang lebih menjurus kepada mementingkan kebajikan manusia berbanding dengan kebajikan alam sehingga menimbulkan pelbagai masalah ekologi dunia yang amat serius. ${ }^{59}$ Kesedaran tentang sifat Racisme yang menunjangi konsep pembangunan Barat klasik menganggap bangsa Caucasian (Kulit putih) lebih tinggi kedudukannya jika dirujuk kepada ras dan kepandaian. Secara asasnya falsafah Euro-Centric ini berpunca daripada paradigma evolutionism ciptaan Charles Darwin yang menganggap tamadun barat sebagai lebih tinggi dan agung, berbanding dengan keadaan masyarakat timur. ${ }^{60}$

Kedua, perubahan nama dan fokus kajian daripada kajian agama Islam per se kepada kajian kawasan (Regional studies). Rata-ratanya nama Oriental Studies telah diubah kepada nama Islamic Studies yang mengkhususkan kajian terhadap pelbagai kawasan umat Islam merangkumi kawasan Timur Tengah, Indo-Pakistan, Asia dan Afrika. Seiringan dengan perubahan ini penekanan yang diambil oleh pusat kajian ini (seperti Middle Eastern Studies dan Near Eastern Studies) lebih bersifat pragmatis dan menumpukan kepada pelbagai isu komtemporari.

Ketiga, Pusat Kajian Orientalisme memang mengamalkan pendekatan autokritik dan terbuka dengan perubahan. Ianya timbul akibat daripada kritikan hebat yang dikemukakan oleh Edward Said sehingga menuntut pihak mereka melakukan proses reviewing terhadap pendekatan metodologi silam yang memang sedia terpakai, merangkumi kajian yang berasaskan prasangka negatif terhadap Islam. Hal ini ditegaskan oleh Watt sebagai:

one of the feauters of the second half of the twentieth century is the great increase in contacts between adherents of different religious. A consequence of this is that it is no longer possible for the occidental 
scholar to pointificate about the religious of Asia as he did in the nineteeth century. The adherent of this religions now being to the same intellectual world as the occidental scholar and will criticize him if he fails to understand and appreciate their religion as a religion. ${ }^{61}$

Hasilnya, mereka mula memberikan penekanan kepada kajian keagamaan yang lebih berbentuk dialog peradaban yang turut membabitkan pelbagai agama dunia yang berbeza. Antara pusat kajian yang menggunakan pendekatan ini ialah Centre of Study Islam and Christian di Birmingham England, George Town University di Amerika Syarikat dan Hartford Seminary di Amerika Syarikat. Antara lainnya pendekatan yang diamalkan oleh pusat kajian ini adalah penekanan secara berhemah dan bersyarat terhadap dialog peradaban serta konsep pluralisme agama yang boleh diperincikan sebagai ${ }^{62}$ sifat memahami perbezaan dan persamaan untuk mencapai kerukunan hidup manusia, sifat dan keadaan interaksi yang harmonis dan tinggi, bukannya bersifat relativis - tetap percaya dengan keunggulan ajaran pegangan masingmasing sebagai agama yang paling sempurna dan bukan bersifat sinkretism yang bakal melahirkan agama lain yang tersendiri.

Dalam setiap forum yang dijalankan pusat kajian ini amat menekankan kepada pengamalan etika dialog agama yang bersifat positif yang boleh diperincikan sebagai ${ }^{63}$ disertai oleh golongan pakar dan penganut yang komited, mengenalpasti isu yang didialogkan untuk kepentingan manfaat bersama, diiringi dengan sifat yang baik dan ingin belajar yang tinggi, lebih memberikan penekanan kepada isu-isu persamaan tentang bagaimana agama boleh menyelesaikan masalah manusia, tidak mengandungi unsur perdebatan yang boleh menjatuhkan maruah puak yang lain, tidak bertujuan memperkecilkan dan mengubah sesuatu pegangan agama pihak lain, tidak mempertikaikan bahagian agama yang bersifat tetap dan tidak boleh berubah dan mengalakkan setiap peserta dialog mempelajari dan memahami kepelbagaian tamadun yang berbeza.

Keempat, Pusat Kajian Orientalism telah mengabungkan kajian Islam dalam kaedah normatif dan historis. Apa yang jelas paradigma ini mengabungkan antara apa yang terdapat di dalam teks dengan realiti semasa yang wujud dalam masyarakat. Hasilnya, setiap pelajar digalakkan untuk mengetahui asas-asas teori ajaran Islam yang berasaskan kepada teks yang asasi (Quran, Sunnah dan warisan ulama silam) yang dihubungkan secara langsung dengan apa yang berkembang dalam masyarakat Islam semasa. 
Kelima, Pusat Kajian Orientalisme menggunapakai pendekatan filosofis sepenuhnya dalam sistem pengajian keilmuan Islam. Hal ini kemudiannya telah mencetuskan pelbagai dinamisme yang berkaitan dengan perkembangan metodologi terkini dan dapatan kajian yang lebih bersifat terbuka. ${ }^{64}$ Apa yang jelas, tanpa menafikan sifat negatif yang memang terdapat dalam kaedah pengajian ala orientalisme, sistem pengajian Islam Barat yang berteraskan falsafah sejarah ini memang bersifat terbuka dan tanpa sifat fanatik walaupun terhadap tokoh ternama orientalis sendiri. Dalam pendekatan pengajaran yang diajarkan terdapat tiga perkara penting ditekankan iaitu pendekatan yang menjadikan karya sarjana Islam dan orientalis (seperti karya Ignaz Goldziher, Joseph Schacht, Patricia Crone, John Burton dan sebagainya) sebagai bahan kajian yang amat digalakkan kepada setiap pelajar untuk menganalisis, mengkritik dan mengemukakan pandangan baru dalam setiap isu yang dibentangkan.

Pendekatan ini mendapat dorongan dan pengawasan sepenuhnya oleh para pengajar yang rata-ratanya terdiri dari kalangan sarjana orientalis sendiri. ${ }^{65}$ Hasilnya, pelajar dilatih dan dipaksa untuk bersikap kritikal sehingga melahirkan pelbagai teori baru yang diutarakan oleh sarjana orientalis sendiri yang mengkritik dan menolak sama sekali teori lama ala reductionist yang berkaitan dengan hukum Islam. ${ }^{66}$ Antara teoriteori ini seperti teori yang menerangkan tentang ajaran Islam sebenarnya tidak mempunyai rumusan yang bersifat hukum, yang sebenarnya dikatakan telah diciplak daripada pengaruh budaya dan agama lain. ${ }^{67}$ Teori yang mengatakan bahawa perundangan Islam telah menjadi tertutup dan beku selepas tertutupnya pintu ijtihad pada abab ke-4 hijrah. Sebaliknya sepertimana ditegaskan oleh Hallaq, proses dialektika antara sistem fiqh Islam dengan realiti sesuatu masyarakat masih lagi berlangsung di zaman taqlid, kerana seseorang sarjana Islam yang melakukan aktiviti syarah dan muhktasar terhadap karya imam mujtahid turut memasukkan komentar pandangan mereka sendiri terhadap realiti yang berlaku di zaman mereka. ${ }^{68}$

Teori penggunaan kaedah kajian biblical texts (Higher criticism) yang dipakai untuk membuktikan kesalahan kitab Bible yang kemudiaanya dipakai untuk membukti kesilapan al-Quran. ${ }^{69}$ Teori backward-projection yang digunakan untuk membuktikan hadis sebagai ciptaan palsu umat Islam yang dikatakan telah berasal daripada kata-kata Nabi Muhammad, kerana kononnya tidak ditemui manuscrip klasik catatan hadis. ${ }^{70}$ Teori tertolak apabila ditemui manuskrip catatan hadis klasik yang berasal daripada zaman Rasulullah sendiri, yang diusahakan oleh sarjana Barat sendiri iaitu Nabia Abbot $^{71}$ dan mendapat kupasan bermakna oleh Mustaffa Azami, bekas pelajar lulusan Universiti Cambridge. ${ }^{72}$ Seterusnya, 
penolakan teori anti hadis ini telah diperjuangkan dengan cukup berkesan oleh Hallaq ${ }^{73}$ dan David Powers. ${ }^{74}$

Hasil dapatan kajian mana-mana tokoh orientalis perlu dibentang dan diperdebatkan di dalam seminar atau simposium kajian orientalisme, Middle East Studies Association (MESA), yang biasa akan dihadiri oleh sejumlah besar pakar dari kalangan penganut Islam dan bukan Islam. Dalam seminar ini, mana-mana pandangan, pendekatan dan teori yang berkaitan dengan subjek orientalis perlu dipertahankan dan akan dinilai dalam suatu mekanisme penilaian yang agak ketat. ${ }^{75}$ Mengikut amalan pengajian di Barat, sesuatu kajian yang baik perlu mengikuti perkembangan sesuatu teori baru dan metodologi kajian ilmiah yang sentiasa berkembang.

Pada mulanya kajian yang diusahakan oleh orientalis tidak menggunakan kaedah ilmiah yang betul seperti menggunakan sumber mitos ${ }^{76}$ yang bersifat anti Islam, ${ }^{77}$ tetapi hal ini telah mula berubah apabila genre orietalisme Barat telah terpengaruh dengan perkaedahan saintifik yang dibawa oleh gerakan Renaissance. ${ }^{78}$ Berbanding dengan keadaan dunia akademik umat Islam pada masa itu yang berpusat di Timur Tengah yang terjebak dalam budaya taqlid dan mengabaikan pengetahuan sains, ${ }^{79}$ dunia akademik Barat yang berpusat di Eropah ternyata telah menerimapakai kaedah saintifik ini yang menjadikan mereka lebih bersifat progresif dengan pelbagai pencapaian sains dan teknologi yang agak tinggi. ${ }^{80}$ Kemudiannya, bidang pengajian orientalis Barat yang menumpukan perhatian terhadap masyarakat di sebelah Timur, yang termasuk di dalam kategori ilmu kemanusiaan telah turut diresapi dengan elemen pengkaedahan saintifik ini. ${ }^{81}$

Akibat langsung perubahan pendekatan metodologi kajian ini sebagai contohnya boleh dilihat daripada penolakkan sarjana orientalis sendiri terhadap metodologi kajian ala sekularisme ${ }^{82}$ seperti kaedah Historicisme yang anti kepada sesuatu ajaran agama ${ }^{83}$ kepada suatu pendekatan kajian Islam yang lebih baik yang dikenali dengan kaedah fenomenologi (ethno methodology) yang mengkaji sesuatu objek dari kaca mata penganut objek yang dikaji. ${ }^{84}$ Dalam pendekatan ini, pemahaman terhadap sesuatu pegangan keagamaan hanya boleh dibuat dengan cara memasuki alam fikiran masyarakat yang dikaji untuk mengetahui sebab utama sesuatu perlakuan yang berkait dengan nilai-nilai kegamaan dibuat oleh penganutnya. ${ }^{85}$ Maksudnya, kajian ini terpaksa mengambil kira soal luaran dan dalaman (spiritual) yang menjadi pendorong kepada sesuatu tindakan. Dalam soal ini, banyak sarjana luar yang cuba untuk mengkaji Islam telah terkeliru kerana bergantung kepada sumber yang diberikan oleh sarjana orientalis yang memusuhi Islam. 
Ringkasnya, sebagai akibat pengamalan pendekatan filosofis ini yang disertakan dengan penggunaan kaedah yang betul, telah lahir beberapa orang sarjana orientalis baru yang lebih bersimpati dengan ajaran Islam. ${ }^{86}$ Secara jelas, orientalis dari kategori ini rata-ratanya telah tertarik dengan ketokohan Rasulullah ${ }^{87}$ berbanding dengan tokoh-tokoh dunia yang lain..$^{88}$ Di samping itu, tindakan yang memberi gambaran positif ini timbul kerana mereka merasa tertekan dengan serangan anti agama yang dikenakan oleh fahaman sekularisme terhadap agama Kristian, ${ }^{89}$ berbanding dengan ajaran Islam yang lebih bersifat toleransi terhadap agama Kristian. Keadaan ini juga kemudiannya telah mendorong mereka mengambil sikap yang lebih simpati dan mengakui kebenaran ajaran Islam. ${ }^{90}$

\section{Kajian Ketamadunan Islam Di Alam Melayu Dan Peranan Sarjana Islam : Analisis Terhadap Peranan Yang Perlu Dimainkan}

Untuk konteks zaman moden ini, para sarjana orientalis masih lagi menumpukan perhatian mereka terhadap subjek tamadun dan pemikiran Islam di rantau Alam Melayu. Sesetengahnya memang ada yang memberikan gambaran yang positif tentang subjek ini, walaupun ia sering dipersembahkan dalam bentuk yang bersesuaian dengan world-view sekularisme moden. ${ }^{91}$ Oleh itu, beberapa contoh khusus yang boleh diberikan adalah seperti:

Pertama; kajian Peter Riddel yang memberikan maklumat tentang perkembangan ilmu tafsir di Alam Melayu. Dalam kupasan beliau dapat diketahui bagaimana keilmuan asas Islam yang berasaskan kepada ilmu Tafsir Al-Quran masih lagi dipegang dan diamalkan secara kuat oleh masyarakat di rantau ini..$^{92}$

Kedua; kajian M.B. Hooker yang memberikan gambaran terkini tentang bagaimana masyarakat Islam di Indonesia masih berpegang kepada amalan bermazhab Ahlu Sunnah Wal Jamaah dalam menyelesaikan sesuatu masalah hukum yang timbul di dalam masyarakat.

Ketiga; kajian Virginia Matherson yang memberikan gambaran tentang bagaimana kitab Jawi yang merupakan warisan leluhur masyarakat Melayu silam secara kuat masih dijadikan rujukan utama di pelbagai institusi pendidikan Islam. ${ }^{93} \mathrm{Hal}$ ini sebaliknya telah mula dilupakan oleh pengkaji Melayu sendiri. Kajian beliau ini boleh dikatakan sebagai agak komprehensif yang biasanya akan dirujuk oleh mana-mana pengkaji terkemudian yang berminat dengan subjek tersebut. 
Keempat; kajian yang dilakukan oleh Martin Van Bruinessen yang memperincikan kesemua kitab Jawi yang digunakan secara meluas dalam sistem pengajian pesantren di Indonesia. Beliau telah bersusah payah mencari dan mengklasifikasikan karya-karya ini mengikut disiplin pengajian Islam yang berbeza. ${ }^{94}$

Kelima; kajian yang dijalankan oleh John Esposito, ${ }^{95}$ Von Der Mehden ${ }^{96}$ dan William Roff ${ }^{97}$ tentang perkembangan pemikiran politik, kesedaran kebangkitan dan intelektual Islam di Malaysia, dalam bentuk yang agak mendalam dan mengambilkira kesemua faktor yang berkaitan.

Keenam; kajian yang dijalankan oleh Donald Horozwitz ${ }^{98}$ yang agak komprehensif memperincikan program pembangunan hukum Islam dan semua organisasi perundangan Islam yang diusahakan oleh pihak kerajaan Malaysia semasa.

Ketujuh; kajian Learnard Binder, Kurzman dan Howard Finderspel yang menumpukan kajian terhadap dinamisme pemikiran Islam di Indonesia yang agak komprehensif. ${ }^{99}$

Proses pemikiran autokritik dan proaktif dalam membangunkan tamadun Melayu-Islam, peniruan terhadap apa yang telah diusahakan oleh sarjana orientalis, termasuklah perlu menghargai warisan karya tradisi ulama Melayu silam menjadi asas kekuatan masyarakat Melayu. Hal ini ditegaskan bagi mengelakkan masyarakat Melayu mengalami penyakit kekeringan jiwa kerana penolakan agama (faham sekularisme) seperti di alami oleh masyarakat Barat. Sepertimana dinyatakan oleh Muhammad Kamal Hassan, sebahagian besar masyarakat Barat yang terdiri daripada sarjana, CEO, hakim dan Islamis mengakui bahawa fenomena keruntuhan moral yang berlaku di Barat adalah sebagai akibat langsung daripada tindakan manusia Barat yang meninggalkan agama dalam kehidupan dan lebih mementingkan nafsu serta materialisme semata-mata, yang kononnya mampu memberikan kebahagiaan sejati kepada umat manusia. ${ }^{100}$ Penekanan terhadap isu moral untuk manusia (bagi makanan rohani) mula disedari oleh sarjana Barat bukan boleh bergantung kepada sumber akal semata-mata, tetapi memerlukan kepada sentuhan ajaran agama. Ini kerana agama dilihat mampu memberikan input kerohanian untuk jiwa manusia tentang tujuan hidup dan matlamat serta kesudahan hidup manusia. ${ }^{101}$

Jika dilihat dari usaha yang dilakukan oleh sarjana oreintalis, ia adalah berdasarkan kepada penyelidikan ilmiah yang betul kerana keperluan menggali intipati dan kandungan warisan karya moral ulama Melayu- 
Islam adalah perkara yang penting. ${ }^{102}$ Hasil dapatan kajian ini kemudiannya perlu dihidupkan secara fungsional bagi menyelesaikan masalah masyarakat semasa. Mengikut Osman Bakar, masyarakat Melayu silam melalui karya moral ulama Melayu-Islam yang mempunyai formula yang cukup tuntas bagi menghadapi isu polarisasi kaum di Malaysia. Hal ini mula disedari oleh masyarakat Barat yang dilihat telah berhadapan dengan permasalahan perkauman yang cukup kronik. ${ }^{103}$

Sehubungan itu, keperluan untuk belajar dan meniru semangat passion for meaning yang tergolong dalam konsep budaya ilmu didapati telah diamalkan oleh sarjana orientalis yang suka mengkaji isu-isu berkaitan dengan masyarakat dan tamadun Alam Melayu sehingga sekarang. Selain itu, mereka juga sentiasa mengikuti perkembangan pemikiran dan peristiwa yang berlaku di dalam masyarakat, agar semua data terkini yang diperoleh dapat dipergunakan sepenuhnya untuk tujuan membangunkan tamadun Islam di Malaysia. Kewujudan faktor negatif secara langsung telah menyebabkan kegagalan untuk melaksanakan pembangunan tamadun Islam. Jika dilihat daripada faktor positif pula, ia mungkin dapat diperkasakan lagi untuk tujuan ini. Antara langkah lain ialah perlu membangunkan konsep kajian regional studies yang membabitkan masyarakat Islam di seluruh dunia. Cadangan yang wujud bukan untuk membezakan kawasan umat Islam yang tertentu, tetapi bagi mengetahui sesuatu perkembangan yang timbul mengikut aspek kontekstualnya yang tertentu. Setiap kawasan umat Islam secara pastinya mempunyai nisbah dan identiti yang tertentu (rencam sifatnya). Daya mentaliti penganut Islam di Alam Melayu adalah berbeza dengan kawasan lain. Atas dasar ini, penolakan teori yang mengangap Islam di Alam Melayu adalah bersifat pinggiran (kurang murni) berbanding dengan Islam Timur Tengah yang kononnya lebih bersifat murni (Ortodok). Dalam perkembangan yang terbaru, didapati Islam mengikut versi Alam Melayu lebih bersifat progresif dan bakal menjadi tapak perkembangan yang lebih subur lagi.

\section{Kesimpulan}

Sebagai kesimpulan, dapat dirumuskan beberapa perkara yang utama. Pertama, berasaskan kepada kriteria ilmiah, ia perlu memandang positifselektif terhadap genre orientalisme memandangkan memang banyak elemen positif yang terkandung di dalamnya khususnya yang membabitkan kajian ketamadunan Islam di Alam Melayu. Hal ini secara langsung telah mencetuskan intellectual discourse dan sikap responsif daripada sarjana Islam yang menolak mana-mana teori yang salah yang diutarakan oleh sarjana orientalis. Kedua, genre orientalisme yang berkaitan dengan metodologi kajian Islam secara amnya dan subjek 
tamadun Islam di Alam Melayu secara khususnya bukanlah bersifat monolitik dan statik, tetapi ianya selalu berkembang pesat. Hal ini boleh dilihat daripada sifat paradigma pemikiran barat yang sentiasa terbuka dengan perubahan dan keilmuan moden. Ketiga, peniruan pendekatan dan semangat suka mengkaji yang dimiliki oleh sarjana orientalis, khususnya yang membabitkan kajian ketamadunan Melayu-Islam, dan sudah sampainya kalangan sarjana Melayu-Islam di Malaysia mewujudkan kajian keIslaman ataupun memperkasakan lagi pusat kajian oksidentalisme (IKON) yang memang sedia wujud di Universiti Kebangsaan Malaysia.

\section{Nota}

1 Lihat Adian Husaini, Wajah Peradaban Barat, Jakarta: Gema Insani, 2005.

2 Syamsuddin Arif, Orientalis dan Dianolisme Pemikiran, Jakarta: Gema Insan, 2008, hlm. 143-147.

3 Daud Rasyid, Pembaruan Islam Dan Orientalisme Dalam Sorotan, Jakarta: Media Akbar, 2002, hlm. 117-125.

4 Mohammad Kamil Abdul Majid, "Pusat Kajian Orientalism: Analisis Terhadap Sikap Umat Islam", dibentang dalam International Seminar On Research In Islamic Studies, Anjuran APIUM pada 17-18 Disember 2008.

5 Rahimin Affandi Abd Rahim, "Etika Kepimpinan Islam Dan Isu Pembangunan Di Malaysia: Satu Analisis ", dalam Prosiding Seminar Kepimpinan Islam Peringkat Antarabangsa, Anjuran APIUM, pada 10-11 Julai 2007, hlm. 34-47.

6 Fred R. Von Der Mehden, Two Worlds OfIslam: Interaction Between Southeast Asia And The Middle East, Florida: Oxford University Press, 1993, hlm. 83-85.

7 Maklumat lanjut boleh didapati dalam Fawaz A. Gerges, America And Political Islam; Clash Of Cultures Or Clash Of Interest, Cambridge: Cambridge University Press, 1999, hlm. 21-28.

8 Maklumat lanjut boleh didapati dalam Abdul Rahman Embong, Pembangunan Dan Kesejahteraan : Agenda Kemanusiaan Abad Ke-21, Syarahan Perdana Jawatan Professor, Pada 26 September 2003, Bangi: Penerbit UKM.

9 Kata pengantar Wan Mohd Nor Wan Daud di dalam buku Syed Muhammad Dawilah al-Edrus, Epistemologi Islam: Teori Ilmu Dalam Al-Quran, Kuala Lumpur: DBP, 1999, hlm. xv.

${ }^{10}$ Imam Syaukani, Rekonstruksi Epistemologi Hukum Islam Di Indonesia, Jakarta: PT Raja Grafindo Persada, 1999, hlm. 67-86.

11 Rahimin Affandi Abd. Rahim, "Pengamalan Ilmu Usul Al-Fiqh Di Dalam Sastera Undang-Undang Melayu: Satu Analisa", dalam Muhammad Mokhtar Hassan (ed.), Kesusasteraan Dan Undang-Undang, Kuala Lumpur: Penerbitan Akademi Pengajian Melayu, Universiti Malaya, 2003, hlm. 158-179.

12 Syed Muhammed Naquid al-Attas, Preliminary Statement on a General Theory of The Islamization of The Malay-Indonesian Archipelago, Kuala Lumpur: DBP, 1969.

${ }^{13}$ Lihat Abdul Aziz Mat Ton, Politik al-Imam, Kuala Lumpur: DBP, 2000. 
${ }^{14}$ Muhammad Redzuan Othman, "The Role of Makka-educated Malays in the Development of Early Scholarship and Education in Malaya", Jurnal of Islamic Studies, v. 9:2, 1988.

${ }^{15}$ Lihat Just World Trust (JUST), "Terrorising The Truth: The Shaping Of Contemporary Images Of Islam And Muslims In Media, Politics And Culture", Prosiding Kepada International Workshop Anjuran Just World Trust (JUST) pada 7-9hb. Oktober 1995, hlm. 29-31.

16 Kalim Siddiqui, Ke Arah Revolusi Islam, terjemahan Hanapi Dolah, Kuala Lumpur: Islamic Book Trust, 1996.

17 Lihat Muhammad Nejatullah Siddiqi, "The Philosophy and the Nature of Islamic Research", dalam Conceptual and Methodological Issues in Islamic Research, Kuala Lumpur: Open Press Publication, 1996, hlm. 73-78.

${ }_{18}$ Asaf Hussain, "The Ideology of Orientalism", Orientalism, Islam and Islamist, Vermont: IIIT, 1984, hlm. 5-22.

${ }^{19}$ Hamid Alqar, "The problem of Orientalist", Islamic Literature, v. xvii:2, 1971, hlm. 35 .

20 A. Wright dan T.H. Reid, The Malay Peninsula, London: T. Fisher Unwin, 1912, hlm. 315.

${ }^{21}$ E. G. De Eredia, "The Description of Malacca", JMBRAS, v. 8:1, 1930, hlm. 31.

${ }^{22}$ T.S. Raffles, Memoir of The Life and Public Services of Sir Stamford Raffles, London: James Duncan Ltd, v. 1, 1930, hlm. 91 dan 288-289.

23 W. L. Richmond, The Modern Malay, London: George Allen \& Unwin Ltd, 1928, hlm. 95 dan 223.

${ }^{24}$ F. Swettenham, Malay Sketch, Singapore: Graham Brash, 1895, hlm. 2-3.

${ }^{25}$ Dalam soal ini Winstedt dengan fanatiknya telah menegaskan: Though his very name has been forgotten at Kuala Kangsar, Captain James Low was the saviour of Perak.. and along with the name of Low, Perak ought to enscribe in the letters of gold the name Robert Fullerton, Governor of Prince of Wales Island, Singapore and Malacca. Lihat R.O. Winstedt, "A History of Perak", JMBRAS, 12:1, 1934, hlm. 73.

${ }^{26}$ R. Wheeler, The Modern Malay, London: George Allen \& Unwin Ltd, 1928, hlm. 200.

${ }^{27}$ Sebagai contohnya seorang sarjana British dalam menceritakan kepentingan mempelajari budaya Melayu telah menegaskan: an understanding of the ideas and modes of thought of an alien people in a relatively low stage of civilization facilitates very considerably the task of governing them. Lihat W.W. Skeat, Malay Magic: Being in Introduction to The Folklore and Popular Religion in The Malay Peninsula, New York: George Allen \& Unwin Ltd, 1967, hlm. ix.

${ }^{28}$ Khasnor Johan, "Perkhidmatan Tadbir Melay: Tradisi dan Peranan Dalam Konteks Kerajaan Penjajah", dalam Malaysia: Sejarah dan Proses Pembangunan, Kuala Lumpur: Persatuan Sejarah Malaysia, 1979, hlm. 134-145.

${ }^{29}$ Edward Said, Covering Islam, How The Media and The Experts Determine Hows We See The Rest of The World, London, 1981, hlm. 39-40, 60 dan 62.

${ }^{30}$ Zainal Kling, Antropologi Tafsiran: Sumbangan Kebudayaan Melayu Kepada Teori, Syarahan Perdana Untuk Pengukuhan Profesor, Kuala Lumpur, 1994, hlm. $12-$ 13. 
31 Sebagai contohnya Frank Swettenham menyatakan bagaimana Raja Muda Abdullah telah meminta kuasa British untuk campurtangan di Negeri Perak dengan tujuan : to teach him how to rule this unruly country, but the circumstances alone made that interference the duty of the paramount power. Lihat $F$. Swettenhan, About Perak, Singapore, 1893, hlm. 5-9.

32 Wang Gungwu, Scholarship and The History and Politics of Southeast Asia, Flinders University of South Australia, 1970, hlm. 11.

${ }_{33}$ Maklumat lanjut boleh didapati dalam Abu Hassan Sham dan Mariyam Salim, Sastera Undang-undang, Kuala Lumpur, 1995, hlm. xi-xxi.

34 Maklumat lanjut boleh didapati dalam Rahimin Affandi Abdul Rahim, Islamic Legal Reform in the Administration of Islamic Law in Malaysia: A Critical Analysis, Tesis Ph.D, University of Birmingham, 1999, hlm. 332-334.

35 F. Swettenham, Malay Sketch, Singapore, 1895, hlm. 3.

36 F. Swettenham, British Malaya, London, 1955, hlm. 136-141.

${ }_{37}$ Maklumat lanjut boleh didapati dalam Rahimin Affandi Abdul Rahim, "Budaya Taqlid di dalam Masyarakat Melayu: Suatu Tinjauan Ringkas", Jurnal Syariah, v. 3, bil. 1, 1995, hlm. 37-38.

38 Zainal Kling, Antropologi Tafsiran: Sumbangan Kebudayaan Melayu Kepada Teori, hlm. 8-10.

39 Ibid.

40 Bryan S. Turner, "Gustave E. Von Grunebaum and the mimesis of Islam", Orientalism, Islam and Islamist, 1999, hlm. 193-202.

41 J.C. Leur, Indonesian Trade and Society, The Hague, 1955, hlm. 169; K.P. Landon, Southeast Asia: Crossroad of Religions, Chicago, 1949, hlm. 134-164.

42 Ahmad Shalaby, Masyarakat Islam, Prof. Mukhtar Yahya (terj.), Singapore, 1966, hlm. 349.

43 Zakaria Stapa, Masyarakat Islam dan Isu Semasa, Kuala Lumpur: DBP, 1994, hlm 56-58.

44 Shamsul Amri Baharuddin, "Antropologi dan Pembangunan: Ke Arah Mencari Hubungan yang Bermakna", dalam Metodologi dan Penyelidikan Dalam Pengajian Melayu, Kuala Lumpur: Penerbit UKM, 1990, hlm. 69-71.

45 Hamid Alqar, "The problem of Orientalist", Islamic Literature, v. XV11:2, 1971, hlm. 35.

46 Shamsul Amri Baharuddin, "Antropologi dan Pembangunan".

47 Ahmad Ghorab, Subverting Islam: The Role OfOrientalist Centres, Kuala Lumpur: Open Press Publication, 1995, hlm. 3.

48 Ibid, hlm. 4.

${ }^{49}$ Ibid., hlm. 12.

${ }^{50}$ Kalim Siddiqui, Ke Arah Revolusi Islam, terjemahan Hanapi Dolah, Kuala Lumpur: Open Press, 1996, hlm. 24-26.

51 Fawaz A. Gerges, America and Political Islam; Clash OfCultures Or Clash OfInterest, Cambridge: Cambridge University Press, 1999, hlm. 16.

52 Gordon D. Newby, "Muslim/Non-Muslim Relations: Lesson From The Past For A Better Future", dalam Aidit Haji Ghazali (ed.), Development, Islamic, Malaysian and American Perspectives, Kuala Lumpur: INMIND, 1996, hlm. 49-50. 
${ }_{53}$ Muhammad Kamal Hasan, Intellectual Discourse At The End Of The Second Millennium: Concerns Of A Muslim-Malay CEO, Kuala Lumpur: UIAM, 2001, hlm. 113-116.

${ }^{54}$ Lihat Rahminah Muharam, "Hubungan Islam dan Kristian Dalam Konteks Dokumen Vatican 11", Pemikir, Oktober-Disember 2000, hlm. 202-212.

${ }_{55}$ Kuntowijoyo, "Epistemologi dan Paradigma Ilmu-ilmu Humaniora dalam Perspektif Pemikiran Islam “, dalam Akh. Minhaji (ed.), Menyatukan Kembali Ilmuilmu Agama dan Umum: Upaya Mempertemukan Epistemologi Islam dan Umum, Yogyakarta: Sunan Kalijaga Press, 2003, hlm. 66-67.

${ }^{56}$ Lihat Abdul Rahman Embong, "Wacana Globalisasi", dalam Noraini Othman dan Sumit Mandal (eds.), Malaysia Menangani Globalisasi: Peserta atau Mangsa, Bangi : Penerbit UKM, 2000, hlm. 23-25.

${ }_{57}$ Mahathir Mohamad, Globalization and The New Realities, Kuala Lumpur: Pelanduk Publication, 2002, hlm. 21-23.

${ }^{58}$ Ali M. Mazrui, "The Ethics Of War And The Rhetoric Of Politic: The West And The Rest", Islamic Millenium, v. 2, no. 2, January-March 2002, hlm. 1-10.

${ }^{59}$ Zaini Ujang, "Tinjauan Terhadap Pendidikan Bersepadu : Suatu Sorotan Dalam Pengajian Kejuruteraan Alam Sekitar", Jurnal Pendidikan Islam, v. 2, bil. 1, 1989, hlm. 39-42.

${ }^{60}$ Edward Said, Covering Islam, hlm. 39-40, 60 dan 62.

${ }^{61} \mathrm{M}$. Watt, Bell S, Introduction To The Quran, Edinburgh: Edinburgh University Press, 1970, hlm. xi.

${ }^{62}$ Harun Nasution, Islam Rasional: Gagasan dan Pemikiran, Bandung: Mizan, 1998, hlm. 275.

${ }^{63}$ Lihat Mohammad Khatami, Membangun Dailog Antara Peradaban: Harapan dan Tantangan, Bandung: Mizan, 1998, hlm. 168.

${ }^{64}$ Untuk maklumat lanjut sila lihat Rahimin Affandi Abdul Rahim, "Orientalisme dan Keutuhan Ummah Islam: Suatu Analisis", Jurnal Syariah, v. 9, bil. 1, 2000, hlm. 39-41.

${ }^{65}$ Maklumat lanjut boleh dilihat dalam Ratno Lukito, "Studi Hokum Islam antara IAIN dan McGill", dalam Yudian W. Asmin (ed.), Pengalaman Belajar Islam di Kanada, Yogyakarta: Titian Ilahi Press, 1997, hlm. 152-162.

${ }_{66}$ Maklumat lanjut boleh didapati dalam Ach. Minhaji, "Kontribusi Dr Wael Hallaq Dalam Kajian Hokum Islam", dalam Yudian W. Asmin (ed.), Pengalaman Belajar Islam di Kanada, Yogyakarta: Titian Ilahi Press, 1997, hlm. 115-142.

67 Patricia Crone and Michael Cook, Hagarism: The Making Of The Islamic World, Cambridge: Cambridge University Press, 1977, hlm. viii.

${ }^{68}$ Hallaq, "Ifta and Ijtihad In Sunni Legal Theory: A Development Account", dalam Islamic Legal Interpretation: Muftis and Their Fatwas, Cambridge: Harvard University Press, 1996, hlm. 33-43.

${ }^{69}$ Yusuf Rahman, "A Modern Western Approach To Quran: A Study Of John Wansbrough's Quranic and Its Muslim Replies", Mcgill Journal Of Middle East Studies, v. 5, 1997, hlm. 129-157.

${ }^{70}$ Lihat sebgai contohnya Ahc. Minhaji, "Orientalisme Dalam Bidang Hokum Islam", dalam Amin Abdullah (ed.), Mencari Islam: Studi Islam Dengan Berbagai Pendekatan, Yogyakarta: Tiara Wacana, 2000, hlm. 152-155. 
71 Nabia Abbot, Studies in Arabic Literary Papyri, vo. 11, Quranic Commentary and Tradition, Chicago: The University of Chicago Press, 1967, hlm. 5-63.

72 Mustaffa Azami, Studies in Early Hadis Literature, Beirut: al-Maktab al-Islami, 1978.

73 Wael Hallaq, "From Fatwas to Furu", Islamic Law and Society, v. 1, 1, 1994, hlm. 133.

${ }^{74}$ David Powers, Studies In Qur'an and Hadis: The Formation Of Islamic Law Of Inheritance, Berkeley: The University of California Press, 1986, hlm. 33-89.

75 Thoha Hamim, Islam dan NU: Di Bawah Tekanan Problematika Kontemporer, Surabaya: Diantara, 2004, hlm. 287-291.

76 E.E. Calverley, Islam: An Introduction, The American University in Cairo Press, 1958, hlm. 2-3.

77 Norman Daniel, Islam, Europe and Empire, Edinburgh, 1966, hlm. 6.

78 Mohd Natsir Mahmud, Orientalisme: Al-Quran Di Mata Barat (Sebuah Studi Evaluatif), Semarang, 1997, hlm. 51-54.

79 Taha Jabir al-Alwani, "Taqlid and The Stagnation of the Muslim Mind", The American Journal of Social Sciences, v. 8, no. 3, 1991, hlm. 513.

${ }^{80}$ Idris Zakaria, "Mengapa Melayu Tiada Ahli Falsafah", Pemikir, Oktober-Disember 2000, hlm. 106-114.

81 Mohd Natsir Mahmud, Orientalisme, hlm. 52-55.

82 M. A. Boisard, Humanisme dalam Islam, terjemahan H.M. Rasyidi, Jakarta, 1980, hlm. 36.

83 Ahmad Ghorab, Subverting Islam: The Role OfOrientalist Centres, Kuala Lumpur: Open Press Publication, 1995, hlm. 13-14.

84 Maklumat lanjut tentang pendekatan ini boleh didapati dalam Zainal Kling, Antropologi Tafsiran: Sumbangan Kebudayaan Melayu Kepada Teori, Syarahan Perdana Untuk Pengukuhan Profesor, Kuala Lumpur.

85 J. Waardenburg, Classical Approaches to The Study of Religion, The Hague, 1973, hlm. 412.

${ }^{86}$ Tokoh-tokoh dari golongan ini adalah seperti John Esposito, John Voll, Richard Bulliet, Leon T. Hadar dan ramai lagi. Maklumat lanjut boleh didapati dalam Fawaz A. Gerges, America and Political Islam: Clash OfCultures Or Clash Of Interest, Cambridge: Cambridge University Press, 1999, hlm. 29-34.

87 W.M. Watt, "Carlyle on Muhammad", The Hibbert Journal, v. XLIX, 1951, hlm. 253.

88 Maxime Rodinson, "The Western Image and The Western Studies Of Islam", dalam The Legacy of Islam, Oxford, 1974, hlm. 38-39.

89 M.A. Boisard, Humanisme Dalam Islam, terjemahan H.M. Rasyidi, Jakarta, 1980, hlm. 87.

90 Lihat Rahminah Muharam, "Hubungan Islam dan Kristian Dalam Konteks Dokumen Vatican 11", hlm. 202-212.

91 Hadijah Rahmat, In Search of Modernity: A Study of The Concepts of Literature, Authorship and Notion of Self in Traditional Malay Literature, Kuala Lumpur: DBP, 2001, hlm. 19-22; Muhammad Abu Bakar, "Pandangan Dunia, Ideologi dan Kesarjanaan: Islam, Proses Sejarah dan Rekonstruksi Realiti Sosial", dalam Tinta Kenangan, Sumbangan Sempena Persaraan dan Perlantikan Naib Canselor, Profesor Datuk Mohd Taib Osman, Kuala Lumpur, 1993, hlm. 307-309. 
92 Peter Riddel, Islam and The Malay-Indonesian World, Singapore: Oxford University Press, 2001, hlm. 101-135.

${ }^{93}$ Virginia Matheson dan M.B. Hooker, "Jawi literature in Patani: The maintenance of an Islamic tradition", JMBRAS, v. 61, Part 1, 1988.

${ }_{94}$ Martin Van Bruinessen, Kitab Kuning Pesantren dan Tarekat: Tradisi Islam di Indonesia, Bandung: Penerbit al-Mizan, 1999.

95 John Esposito, Islam and Democracy, New York: Oxford University Press, 1996.

${ }^{96}$ Fred R. Von Der Mehden, Two Worlds Of Islam: Interaction Between Southeast Asia and The Middle East, Florida, 1993.

97 W. Roff, "Patterns of Islamization in Malaysia 1890s-1990s: Exemplars, Institutions and Vectors", Journal Of Islamic Studies, v. 9, no.2, 1998.

98 Donald L. Horowitz, "The Quran and the Common Law: Islamic Law Reform and The Theory of Legal Change", The American Journal Of Comparative Law, v. 42, 1994.

99 Charles Kurzman, Liberal Islam: A sourcebook, New York: Oxford University Press, 1998.

${ }^{100}$ Muhammad Kamal Hasan, Intellectual Discourse At The End Of The Second Millennium: Concerns Of A Muslim-Malay CEO, Kuala Lumpur: UIAM, 2001, hlm. 6-9.

${ }^{101}$ Ibid.

${ }^{102}$ Sebagai contohnya lihat Kim Keum Hyun, Konsep Jadi Orang Dalam Masyarakat Melayu: Satu Kajian Kes Di Negeri Terengganu, Tesis Sarjana, Jabatan Pengajian Melayu, Universiti Malaya, 1995.

${ }^{103}$ Osman Bakar, "Globalisasi dan Peradaban", dalam A. Aziz Deraman, Globalisasi Dalam Peradaban Di Malaysia, Kuala Lumpur: DBP, 2003, hlm. 33-38. 